Отримано: 21 травня 2018 р.

Прорецензовано: 27 травня 2018 р.

Прийнято до друку: 01 червня 2018 р.

e-mail: chornyiav@gmail.com

DOI: $10.25264 / 2311-5149-2018-9(37)-78-84$

Чорний А. В. Сучасні теорії лідерства: загальний огляд та структурна модель. Наукові записки Начіонального університету «Острозька академія». Серія «Економіка» : науковий журнал. Острог : Вид-во НаУОА, червень 2018. № 9(37). С. 78-84.

\author{
Чорний Антон Валерійович, \\ аспірант кафедри менеджменту інноваційної та інвестиційної діяльності \\ Київського національного університету імені Тараса Шевченка
}

\title{
СУЧАСНІ ТЕОРІї ЛІДЕРСТВА: ЗАГАЛЬНИЙ ОГЛЯД І СТРУКТУРНА МОДЕЛЬ
}

У статті розглянуто традиційні та сучасні теорії лідерства, сформульовано їх основні положення, припущення та результати теорій. Теорії класифіковано за їх направленістю (направлені на лідера, на взаємодію лідера та послідовників і на послідовників). Виконано опис загальних характеристик елементів класифікачії: визначення лідерства, переваги, недоліки й умови ефективності. Надано обтрунтування ієрархічності теорій лідерства на базі теорії обмеженої рачіональності, побудовано зв'язки між теоріями лідерства.

Ключові слова: теорія лідерства, структурна модель, розвиток лідерства, лідерська компетенція.

\section{Чёрный Антон Валерьевич,}

аспирант кафедры менеджмента инновационной и инвестиционной деятельности Киевского национального университета имени Тараса Шевченка

\section{СОВРЕМЕННЫЕ ТЕОРИИ ЛИДЕРСТВА: ОБЗОР И СТРУКТУРНАЯ МОДЕЛЬ}

В статье рассмотрены традиционные и современные теории лидерства, сформулированы их основные положения, предположения и результаты теорий. Теории классифиџированы по их направленности (направленные на лидера, на взаимодействие лидера и последователей и на последователей). Выполнено описание общих характеристик элементов классификации: определение лидерства, преимущества, недостатки и условия эффективности. Предоставлено обоснование иерархичности теорий лидерства на базе теории ограниченной рациональности, построено связи между теориями лидерства.

Ключевые слова: теория лидерства, структурная модель, развитие лидерства, лидерская компетенция.

\author{
Anton Chornyi, \\ Postgraduate student at the Management of Innovation and Investment Activities Department, \\ Taras Shevchenko National University of Kyiv
}

\section{MODERN LEADERSHIP THEORIES: OVERVIEW AND STRUCTURAL MODEL}

The article deals with traditional and modern leadership theories, formulates main principles, assumptions and theories results. Theories are classified according to their direction (leader-based, relationship-based and follower-based). The author gives the description of the classification elements'general characteristics: leadership definition, advantages, disadvantages and performance conditions. The justification of the leadership theories hierarchy based on the theory of limited rationality is given, links between leadership theories are constructed.

Key words: leadership theories, structural model, leadership development, leadership competency.

Постановка проблеми. Формування культури лідерства є однією зі складових успішної економіки, наявність розвиненого лідерства дозволяє управляти організацією ефективніше і це стосується як керівника, так і співробітників.

Лідерство не відміняє необхідності управління (менеджменту), але за наявності одних і тих самих ресурсів розвинене лідерство дозволяє отримати більші результати. Тобто розвиток лідерства - це один iз напрямів інвестицій, що не потребує значних фінансових вкладень, але здатен значно покращити фінансові результати.

На сьогодні існує велика кількість наукових позицій щодо питання лідерства: від теорій до опису певних підходів і методів, але немає моделі, що дозволяє визначитися щодо аспектів лідерства, реалізація яких у певній організації дозволить отримувати найкращі результати.

Питання лідерства є актуальним для розвитку управління практично у всіх пострадянських країн, адже лідерство як категорію в радянській системі координат не досліджували і на практиці управління цілеспрямовано не розвивали. 
На сьогодні, зокрема в Україні, питання лідерства зазвичай не є такими, що на практиці сприймають як необхідну складову ефективного управлінця, через те, що поняття лідерства сприймають як якусь захмарну, незбагненну, недосяжну технологію.

Аналіз останніх досліджень і публікацій. Сфера лідерства достатньо добре досліджена сфера в західній традиції управління: основу для подальшого розвитку всіх теорій лідерства заклав шотландський історик Томас Карлайл у книзі «О Героях, поклонінні Героям та героїчному в Історії» $[1 ; 2]$. Робота Карлайла стала основою для формування теорії великої людини, яка визначає, що лідерами народжуються, а не стають. Це дослідження дозволило сформулювати основні поняття й описати лідерство як таке, що надалі послужило понятійною базою для теорій, що описують можливості для формування лідерства.

У середині XX століття були проведені дослідження лідерів, їх якостей і поведінки, що були покладені в теорію людських якостей і поведінкового підходу під час вивчення лідерства [2, с. 37-71], надалі було поєднано ці два питання та пов'язано їх із ефективністю [3, с. 7-52]. Якісно новим напрямом дослідження лідерства стало вивчення взаємодії лідера та послідовників у теоріях трансакційного та трансформаційного лідерства [4]. Пізніше виникали концепції, що робили акцент саме на послідовниках лідера, одна із найрозвиненіших теорій цієї спрямованості - теорія лідерства-служіння [5], інші ретельно описують розвиток лідерства в певній сфері.

У вітчизняній науці питаннями лідерства займаються І. А. Чистякова [6, с. 306-312], О. Г. Романовський, Н. В. Середа [7, с. 20-27], К. Б. Козак [8, с. 24-28], але рівень розвитку досліджень лідерства серед українських дослідників $є$ недостатнім.

Мета та завдання дослідження полягають у формуванні структурної моделі теорій лідерства, яка підтверджує про наявний тісний взаємозв'язок між ними, та визначає перспективи розвитку економічної науки у сфері лідерства. Основними завданнями $є$ аналіз теорій лідерства, їх основних положень, а також визначення обмежень щодо їхнього використання.

Виклад основного матеріалу дослідження. У дослідженні групи дослідників на чолі із Джесікою Дінх [9] викладено теорії лідерства, які сформувалися у XXI столітті. Із додаванням класичних теорій лідерства - отримаємо повний їх перелік.

Водночас основою для класифікації візьмемо спрямування відповідної теорії: на персону лідера, на взаємодію лідера із послідовниками та на послідовників. Отриманий результат представимо в таблиці 1.

Таблиия 1

Основні положення класичних теорій лідерства

\begin{tabular}{|c|c|c|c|}
\hline Назва теорії & Допущення & Результати & Обмеження \\
\hline \multicolumn{4}{|c|}{ Оріснтовані на персону лідера } \\
\hline $\begin{array}{l}\text { Теорії великої } \\
\text { людини } \\
{[1 ; 2] .}\end{array}$ & $\begin{array}{l}\text { Лідерами народжуються, } \\
\text { а не стають. Для того, щоб } \\
\text { бути лідером, необхідно } \\
\text { мати вроджені якості. }\end{array}$ & $\begin{array}{l}\text { Необхідними вродженими якос- } \\
\text { тями лідерів є: харизма, інтелект, } \\
\text { свобода, політичні навички. }\end{array}$ & $\begin{array}{l}\text { Досліджувалися лідери лише з } \\
\text { декількох сфер діяльності (військові, } \\
\text { політики). } \\
\text { Неможливе застосування для роз- } \\
\text { витку лідерів, тому що зроблено } \\
\text { акцент на спадкоємності лідерських } \\
\text { якостей. }\end{array}$ \\
\hline $\begin{array}{l}\text { Теорії особис- } \\
\text { тих якостей } \\
{[2, \text { с. } 35-71]}\end{array}$ & $\begin{array}{l}\text { У різних сферах існують } \\
\text { набори особистих якостей, } \\
\text { які відрізняють лідерів від } \\
\text { інших членів груп. }\end{array}$ & $\begin{array}{l}\text { Сформульовані списки особис- } \\
\text { тих якостей лідерів (наприклад, } \\
\text { «велика п’ятірка») відповідно до } \\
\text { демографічних характеристик. } \\
\text { Такі списки містять майже всі по- } \\
\text { зитивні прикметники. }\end{array}$ & $\begin{array}{l}\text { Неможливість обрати ключові через } \\
\text { занадто широкого кола якостей, } \\
\text { особисті якості розглядаються без } \\
\text { уваги до контексту (ситуацій або по- } \\
\text { слідовників). }\end{array}$ \\
\hline $\begin{array}{l}\text { Поведінковий } \\
\text { підхід } \\
\text { [10, с. 271-276] }\end{array}$ & $\begin{array}{l}\text { Поведінку лідерів можна } \\
\text { вимірювати та відслідко- } \\
\text { вувати її вплив на ефек- } \\
\text { тивність роботи. } \\
\text { Існують певні патерни по- } \\
\text { ведінки, які можна об'єд- } \\
\text { нати у стилі лідерства. }\end{array}$ & $\begin{array}{l}\text { Створення 2-факторних моделей } \\
\text { аналізу поведінки лідерів (став- } \\
\text { лення до результату та до людей). }\end{array}$ & $\begin{array}{l}\text { Брак науково аргументованих дока- } \\
\text { зів стилю, який уважають найбільш } \\
\text { ефективним у теорії дослідження } \\
\text { (високий акцент на завданнях і } \\
\text { стосунках). } \\
\text { Двох факторів замало задля валідно- } \\
\text { го відображення процесу лідерства. }\end{array}$ \\
\hline $\begin{array}{l}\text { Інтегровані } \\
\text { моделі лідерсь- } \\
\text { ких якостей, } \\
\text { поведінки та } \\
\text { ефективності } \\
\text { [11, с. } 7-52]\end{array}$ & $\begin{array}{l}\text { Ефективність лідерів зале- } \\
\text { жить від особистих якос- } \\
\text { тей і моделей поведінки. }\end{array}$ & $\begin{array}{l}\text { Особисті якості та моделі по- } \\
\text { ведінки пояснюють близько } 30 \% \\
\text { ефективності лідерів. } \\
\text { Моделі поведінки мають більшу } \\
\text { прогностичну силу, ніж особисті } \\
\text { якості, проте інтегрована модель } \\
\text { надає більш точніші результати. }\end{array}$ & $\begin{array}{l}\text { Для збору даних щодо лідерських } \\
\text { якостей і моделей поведінки не було } \\
\text { взято до уваги дослідження у сферах } \\
\text { етичного лідерства та лідерства-слу- } \\
\text { жіння, } \\
\text { дослідження було побудовано ви- } \\
\text { ключно на матеріалах щодо теорій, } \\
\text { які стосуються ієрархічних процесів. }\end{array}$ \\
\hline
\end{tabular}


Продовження таблиці 1

\begin{tabular}{|c|c|c|c|}
\hline $\begin{array}{l}\text { Психодинаміч- } \\
\text { ний підхід } \\
{[12, \text { с. } 393]}\end{array}$ & $\begin{array}{l}\text { Розуміння глибинних } \\
\text { особливостей власної } \\
\text { особистості та своїх колег } \\
\text { допомагає ефективніше } \\
\text { взаємодіяти. }\end{array}$ & $\begin{array}{l}\text { Він підкреслює відносини між } \\
\text { лідером та послідовником, тран- } \\
\text { закція між цими двома особами - } \\
\text { універсальність цього підходу. } \\
\text { Також він підкреслює необхід- } \\
\text { ність особистого розуміння з боку } \\
\text { лідера, а також послідовника - це } \\
\text { перешкоджає маніпулятивним } \\
\text { методам лідерства. }\end{array}$ & $\begin{array}{l}\text { Цей підхід базується на клініч- } \\
\text { них спостереженнях та лікуванні } \\
\text { осіб із серйозними труднощами - } \\
\text { суб'єктивна природа висновків клі- } \\
\text { нічних психологів (також культурні } \\
\text { упередження). }\end{array}$ \\
\hline $\begin{array}{l}\text { Ситуаційний } \\
\text { підхід } \\
{[13, \text { с. 321-339] }}\end{array}$ & $\begin{array}{l}\text { Немає лідерських стилів, } \\
\text { які є ефективними в усіх } \\
\text { ситуаціях з окремої гру- } \\
\text { пою послідовників. }\end{array}$ & $\begin{array}{l}\text { Ефективність використання лідер- } \\
\text { ських стилів залежить від ситуації, } \\
\text { рівня структурованості завдань, } \\
\text { рівня зрілості послідовників, } \\
\text { організації й інших зовнішніх } \\
\text { факторів. } \\
\text { Різні стилі лідерства можуть } \\
\text { застосовувати на різних рівнях } \\
\text { організації. }\end{array}$ & $\begin{array}{l}\text { Дослідження більшою мірою грунту- } \\
\text { ються на теоретичних припущеннях } \\
\text { без валідного практичного підтвер- } \\
\text { дження } \\
\text { концепція рівнів зрілості підлеглих є } \\
\text { занадто спрощеною (залежить усьо- } \\
\text { го від декількох факторів). } \\
\text { Більшою мірою дослідження сто- } \\
\text { сується теорії менеджменту, а не } \\
\text { лідерства. }\end{array}$ \\
\hline $\begin{array}{l}\text { Біологічні } \\
\text { підходи до } \\
\text { лідерства } \\
{[14, \text { с. } 1092-} \\
1106][15, \\
\text { c. } 259-272]\end{array}$ & $\begin{array}{l}\text { Дослідження якості та } \\
\text { поведінки лідера, вико- } \\
\text { ристовуючи застосування } \\
\text { соціальної когнітивної } \\
\text { нейронауки для вивчення } \\
\text { механізмів людського } \\
\text { мозку в пізнанні, емоціях } \\
\text { та поведінці. }\end{array}$ & $\begin{array}{l}\text { Завдяки широкомасштабним до- } \\
\text { слідженням сформовані компе- } \\
\text { тенції емоційного та соціального } \\
\text { інтелекту. }\end{array}$ & $\begin{array}{l}\text { Дослідження проводять лише в } \\
\text { лабораторних умовах та за наявності } \\
\text { спеціального обладнання. Резуль- } \\
\text { тати досліджень високою мірою } \\
\text { залежать від обраних дослідниками } \\
\text { інструментів опитування й аналізу } \\
\text { результатів. }\end{array}$ \\
\hline \multicolumn{4}{|c|}{ Орієнтовані на відносини між лідером і послідовниками } \\
\hline $\begin{array}{l}\text { Трансакційне та } \\
\text { трансформацій- } \\
\text { не лідерство } \\
{[16],[17,} \\
\text { c. } 385-425]\end{array}$ & $\begin{array}{l}\text { Основна мета лідера- } \\
\text { побудова відносин із } \\
\text { послідовниками на основі } \\
\text { принципів і цінностей. } \\
\text { Існують компетенції, які } \\
\text { відрізняють найбільш } \\
\text { ефективних лідерів. }\end{array}$ & $\begin{array}{l}\text { Визначені компетенції трансакцій- } \\
\text { них та трансформаційних лідерів. } \\
\text { Методи «батога та пряника» менш } \\
\text { ефективні порівняно з коучингом } \\
\text { та поширенням спільного бачення. } \\
\text { Методи аналізу ситуацій та по- } \\
\text { ведінки послідовників менш } \\
\text { ефективні за лідерство на основі } \\
\text { поширення бачення }\end{array}$ & $\begin{array}{l}\text { Базою для дослідження є інформація } \\
\text { щодо лідерів вищої управлінської } \\
\text { ланки. } \\
\text { Модель трансакційного лідерства } \\
\text { надає незначні поради лідерам, які } \\
\text { повинні збалансувати допомогу } \\
\text { працівникам досягнути їхньої мети з } \\
\text { досягненням групових цілей. }\end{array}$ \\
\hline $\begin{array}{l}\text { Leader-member } \\
\text { exchange theory } \\
\text { (теорія обміну } \\
\text { лідер-послідов- } \\
\text { ник) } \\
\text { [18] }\end{array}$ & $\begin{array}{l}\text { Лідерство є трьохгран- } \\
\text { ним конструктом, який } \\
\text { одночасно залежить від } \\
\text { урахування особливостей } \\
\text { персони лідера, послідов- } \\
\text { ників і відносин між ними. }\end{array}$ & $\begin{array}{l}\text { Обгрунтована концепція дво- } \\
\text { сторонніх відносин від послі- } \\
\text { довником і лідером. Доведено, } \\
\text { що покращення комунікацій між } \\
\text { лідерами та послідовниками по- } \\
\text { зитивно впливає на результати } \\
\text { діяльності. }\end{array}$ & $\begin{array}{l}\text { Розподіл членів колективу на тих, } \\
\text { хто входить у внутрішній круг від- } \\
\text { носин лідера та послідовників, та } \\
\text { тих, хто є аутсайдерами, негативно } \\
\text { впливає на загальний емоційний } \\
\text { стан колективу. }\end{array}$ \\
\hline \multicolumn{4}{|c|}{ Орієнтовані на послідовників } \\
\hline $\begin{array}{l}\text { Лідерство-слу- } \\
\text { жіння } \\
\text { [19] }\end{array}$ & $\begin{array}{l}\text { Ефективне лідерство } \\
\text { проявляється не через } \\
\text { особисту харизму, а через } \\
\text { служіння іншим. } \\
\text { Досягнення добробуту } \\
\text { організації стає можливим } \\
\text { через орієнтацію лідера } \\
\text { на створення відносин } \\
\text { безпеки та служіння по- } \\
\text { слідовникам. }\end{array}$ & $\begin{array}{l}\text { Визначені компетенції для ефек- } \\
\text { тивного лідерського служіння. } \\
\text { Досягнення добробуту організації } \\
\text { стає можливим через орієнтацію } \\
\text { лідера на створення відносин без- } \\
\text { пеки та служіння. }\end{array}$ & $\begin{array}{l}\text { Сфокусованість на дослідженні } \\
\text { одного типу відносин між лідером } \\
\text { та послідовниками, без урахуван- } \\
\text { ня зовнішніх обставин, специфіки } \\
\text { робочих завдань і рівня розвитку } \\
\text { послідовників. }\end{array}$ \\
\hline $\begin{array}{l}\text { Shared leadership } \\
\text { (спільне лідер- } \\
\text { ство) } \\
{[20]}\end{array}$ & $\begin{array}{l}\text { Лідерство відбувається на } \\
\text { всіх рівнях організації і } \\
\text { важливим є систематичне } \\
\text { поєднання різних підходів. }\end{array}$ & $\begin{array}{l}\text { Емпірично доведений зв’язок між } \\
\text { розподіленням ролі лідерства та } \\
\text { високою ефективністю команд за } \\
\text { умови наявності чіткого спільного } \\
\text { бачення, соціальної підтримки та } \\
\text { зовнішніх коучей. }\end{array}$ & $\begin{array}{l}\text { Відсутність розробленого фрейм- } \\
\text { ворку спільного лідерства задля } \\
\text { масового використання. }\end{array}$ \\
\hline
\end{tabular}




\section{Продовження таблиці 1}

\begin{tabular}{|c|c|c|c|}
\hline $\begin{array}{l}\text { Team-leadership } \\
\text { theory } \\
\text { (теорія } \\
\text { командно-го } \\
\text { лідерства) } \\
\text { [21, с. } 451-483]\end{array}$ & $\begin{array}{l}\text { Баланс ролей та функцій у } \\
\text { команді та поведінці ліде- } \\
\text { рів є більш важливим для } \\
\text { досягнення результатів } \\
\text { за індивідуальні характе- } \\
\text { ристики членів команд та } \\
\text { лідерів. }\end{array}$ & $\begin{array}{l}\text { За допомогою емпіричних дослі- } \\
\text { джень охарактеризовано відмін- } \\
\text { ності між соло-лідерами та ліде- } \\
\text { рами команд, розроблено модель } \\
\text { компетенцій командного лідера та } \\
\text { встановлені } 9 \text { ролей командного } \\
\text { лідерства. }\end{array}$ & $\begin{array}{l}\text { Відсутні чіткі інструкції щодо того, } \\
\text { як можна практично розвивати ко- } \\
\text { мандне лідерство. }\end{array}$ \\
\hline $\begin{array}{l}\text { Латеральне } \\
\text { лідерство } \\
\text { [22, с. } 177-189]\end{array}$ & $\begin{array}{l}\text { Задля здійснення лідер- } \\
\text { ства непотрібно бути } \\
\text { формальним керівником. }\end{array}$ & $\begin{array}{l}\text { Визначений перелік ситуацій, } \\
\text { у якому латеральне лідерство є } \\
\text { ефективним (крос-функціональні } \\
\text { проекти; процесні ланцюги ство- } \\
\text { рення цінності, у яких менеджери } \\
\text { можуть бути лише посередниками; } \\
\text { бізнес-партнерство). }\end{array}$ & $\begin{array}{l}\text { Є ефективним в умовах побудови } \\
\text { відносин із вузькопрофільними спе- } \\
\text { ціалістами, продукт діяльності яких } \\
\text { несе високу цінність (IT, маркетинг) } \\
\text { та } є \text { недієвим у відносинах із фахів- } \\
\text { цями рутинної праці. }\end{array}$ \\
\hline $\begin{array}{l}\text { Dispersed } \\
\text { leadership } \\
\text { (розпорошене } \\
\text { лідерство) } \\
\text { [23, с. } 182-204]\end{array}$ & $\begin{array}{l}\text { Лідери колективу визнача- } \\
\text { ються не через їх особисті } \\
\text { характеристики, а через } \\
\text { відносини з послідовни- } \\
\text { ками. }\end{array}$ & $\begin{array}{l}\text { Встановлено зв’язок між понят- } \\
\text { тями «лідерство» та «лідер», їх } \\
\text { спільні та відмінні риси. Обгрун- } \\
\text { тована емерджентність ролі лідера } \\
\text { в командах. }\end{array}$ & $\begin{array}{l}\text { Більшою мірою дослідження прово- } \\
\text { дилися у спортивних командах. }\end{array}$ \\
\hline $\begin{array}{l}\text { Distributed } \\
\text { leadership } \\
\text { (розподілене } \\
\text { лідерство) } \\
{[24, \text { с. } 423-451]}\end{array}$ & $\begin{array}{l}\text { Загальні результати ко- } \\
\text { манди не є тільки сумою } \\
\text { окремих вкладів кожного } \\
\text { члену колективу. }\end{array}$ & $\begin{array}{l}\text { Розроблені фреймворки розподі- } \\
\text { леного лідерства, у яких робиться } \\
\text { акцент на управлінні складністю, } \\
\text { спонтанністю та багатогранністю } \\
\text { відносин у колективі. }\end{array}$ & $\begin{array}{l}\text { Дослідження були проведені у } \\
\text { школах або університетах під час } \\
\text { навчання, а не виконання практичної } \\
\text { діяльності. }\end{array}$ \\
\hline
\end{tabular}

Якщо проаналізувати наведені теорії лідерства, то вони пройшли еволюцію від теорій, орієнтованих на персону лідерства через такі, що орієнтовані на відносини між лідером і послідовниками, та останні теорії лідерства орієнтовані на послідовників. Кожен із наведених типів теорій лідерства (орієнтовані на персону лідера, орієнтовані на відносини між лідером і послідовниками, орієнтовані на послідовників) має чіткі відмінності один від одного, які сформульовано в таблиці 2.

Стадії розвитку теорій лідерства

Таблиияя 2

\begin{tabular}{|c|c|c|c|}
\hline & Оріснтовані на персону лідера & $\begin{array}{c}\text { Орієнтовані на відносини } \\
\text { між лідером та послідовниками }\end{array}$ & $\begin{array}{c}\text { Оріснтовані } \\
\text { на послідовників }\end{array}$ \\
\hline Лідерство - це & $\begin{array}{l}\text { Відповідна модель поведінки } \\
\text { людини, що грає роль лідера. }\end{array}$ & $\begin{array}{l}\text { Процес взаємовпливу між декіль- } \\
\text { кома суб'єктами, який будується } \\
\text { на довірі, повазі та взаємних } \\
\text { зобов’язаннях. }\end{array}$ & $\begin{array}{l}\text { Можливість та мотивація до- } \\
\text { помагати кожному управляти } \\
\text { власною продуктивністю. }\end{array}$ \\
\hline $\begin{array}{l}\text { Складові лідер- } \\
\text { ської поведінки }\end{array}$ & Встановлення візії, надихання. & $\begin{array}{l}\text { Створення міцних відносин } 3 \text { по- } \\
\text { слідовниками; взаємне навчання } \\
\text { та взаємовигідність. }\end{array}$ & $\begin{array}{l}\text { Посилення повноважень } \\
\text { членів колективу, коучінг, } \\
\text { фасилітація, розвиток послі- } \\
\text { довників. }\end{array}$ \\
\hline Переваги & $\begin{array}{l}\text { Простота розуміння та застосу- } \\
\text { вання теорій. } \\
\text { Фокус на найбільш мотивованих } \\
\text { та спроможних членах організа- } \\
\text { ції-лідерах. }\end{array}$ & $\begin{array}{l}\text { Дає можливість отримувати висо- } \\
\text { кі результати в роботі з різними } \\
\text { типами людей. }\end{array}$ & $\begin{array}{l}\text { Значно розширює варіатив- } \\
\text { ність дій членів організації } \\
\text { та мінімізує людські ризики } \\
\text { через сприяння розвитку } \\
\text { послідовників і розкриттю їх } \\
\text { спроможностей. }\end{array}$ \\
\hline Недоліки & $\begin{array}{l}\text { Невідповідність теорій реальним } \\
\text { практичним умовам діяльності } \\
\text { через сімпліфікацію припу- } \\
\text { щень щодо факторів впливу на } \\
\text { лідерську поведінку. } \\
\text { Великий рівень ризику в разі не- } \\
\text { адекватного вибору лідера. }\end{array}$ & $\begin{array}{l}\text { Задля побудови стійких відносин } \\
\text { між лідером та послідовниками } \\
\text { потрібно багато часу. }\end{array}$ & $\begin{array}{l}\text { Потребує високого рівня } \\
\text { свідомості, мотивації та нави- } \\
\text { чок не тільки від окресленої } \\
\text { кількості лідерів, а від усіх } \\
\text { членів організації. } \\
\text { Врахування потреб і мотивів } \\
\text { «knowledge workers» (праців- } \\
\text { ників знань). }\end{array}$ \\
\hline $\begin{array}{l}\text { Умови ефектив- } \\
\text { ності }\end{array}$ & $\begin{array}{l}\text { Фізична праця, розумова праця } \\
\text { низького рівня. }\end{array}$ & $\begin{array}{l}\text { Стабільність складу організації } \\
\text { та зовнішнього середовища. }\end{array}$ & $\begin{array}{l}\text { Високий рівень послідовни- } \\
\text { ків, розумова праця. }\end{array}$ \\
\hline
\end{tabular}

Джерело: розроблено автором на основі [25, с. 219-247]. 
Маємо зазначити, що питання лідерства є таким, що охоплює багато сфер, може проявлятися в різних ситуаціях та умовах. У дослідженнях зазначено, що не знайдено форму та стилю лідерства, що $є$ ефективним у будь-якій ситуації.

Зазначимо, що залежно від конфігурації лідер-послідовники різні підходи будуть давати різні результати. Зрозуміло, що наступні теорії лідерства виникали внаслідок того, що попередні не могли якісно описати наявну ситуацію. Але жодна із наведених теорій не заперечує на $100 \%$ попередньої, адже можуть бути і лідери, які народилися із харизмою, лідери, сформовані на базі формування особистісних якостей, лідери, сформовані, на основі освоєння певних патернів поведінки. Здатність до трансакційного та трансформаційного лідерства не виключає напрацювання ефективних патернів поведінки лідера, так само як самолідерство та застосування психічного підходу не виключає можливості для використання одночасно інших методів і підходів.

Також маємо зазначити, що класичний підхід щодо оцінки людини та їі можливостей для прийняття рішень, зокрема спрямованих на власний розвиток, як раціональний є застарілим. Герберт Саймон [26, c. 16-38] запропонував теорію «Обмеженої раціональності», яка, в подальшому стала однією з основ напрямку «Поведінкової економіки».

Тобто за Саймоном людина має певні обмеження раціональності (інтелекту та уваги), до яких, в подальшому було додано обмеження волі та егоїзму [27, с. 1471-1550]. I якщо певний лідер має певні обмеження, то не всі методи та можливості для розкриття лідерства будуть йому доступні.

Тобто, якщо лідер має велике обмеження егоїзму - він не зможе в короткостроковій перспективі реалізувати можливості лідерства-служіння.

Тим не менше, якщо припустити, що лідери можуть вести роботу щодо зменшення або зняття обмежень раціональності, та напрацьовувати певні навички та якості, то лідер може формувати план розвитку власного лідерства, до якого мають входити відповідні активності.

Можна припустити, що за аналогією із наявності обмежень раціональності в людини існує аналогічна характеристика у спільноти послідовників лідера, яка також задає можливі типи лідерства у відповідній спільності. I для ефективного застосування іншого стилю лідерства необхідний розвиток відповідної спільноти.

Якщо взяти як припущення, що в лідера $є$ всі можливості для зміни себе, значні можливості для формування відносин із послідовниками і лише деякі можливості для зміни безпосередньо послідовників, то буде сформовано модель, за якою обрання актуальної теорії лідерства залежить від поточних можливостей лідера.

Таблиця 3

Зв'язки теорій лідерства

\begin{tabular}{|c|c|c|c|}
\hline № & Назва теорії & $\begin{array}{c}\text { Теорія- } \\
\text { попередник }\end{array}$ & Вимоги \\
\hline 1 & Теорія великої людини & & Лідер має вроджені лідерські здібності \\
\hline 2 & Теорія особистих якостей & 1 & Напрацювання особистих якостей \\
\hline 3 & Поведінковий підхід & 1 & Напрацювання патернів поведінки \\
\hline 4 & $\begin{array}{l}\text { Інтегровані моделі лідерських якостей, поведінки } \\
\text { та ефективності }\end{array}$ & 2,3 & $\begin{array}{l}\text { Напрацювання особистих якостей та патернів } \\
\text { поведінки }\end{array}$ \\
\hline 5 & Психодинамічний підхід & 4 & Глибоке розуміння мотивів власної поведінки \\
\hline 6 & Ситуаційний підхід & 4 & Вміння оцінювати та класифікувати підлеглих \\
\hline 7 & Біологічні підходи до лідерства & 4 & - \\
\hline 8 & Трансакційне та трансформаційне лідерство & $1,5,6,7$ & $\begin{array}{l}\text { Побудова відносин лідера з послідовниками } \\
\text { на основі принципів та цінностей. }\end{array}$ \\
\hline 9 & Vertical dyad linkage & 8 & \\
\hline 10 & Leader-member exchange theory & 9 & Взаємодія лідера та послідовників \\
\hline 11 & Relational leadership & 10 & \\
\hline 12 & Нео-харизматичні теорії & 1,8 & $\begin{array}{l}\text { Лідер має вроджені лідерські здібності, а } \\
\text { також будує відносини із послідовниками }\end{array}$ \\
\hline 13 & Лідерство-служіння & 8 & Служіння цінностям компанії та колегам \\
\hline 14 & \begin{tabular}{|l} 
Спільне лідерство \\
(Shared leadership)
\end{tabular} & 8 & Цінність групового результату \\
\hline 15 & $\begin{array}{l}\text { Командне лідерство } \\
\text { (Team-leadership theory) }\end{array}$ & 8 & Командна робота, розподілені ролі \\
\hline 16 & $\begin{array}{l}\text { Розподілене лідерство } \\
\text { (Distributed leadership) }\end{array}$ & 8 & Схильність до навчання \\
\hline 17 & Латеральне лідерство & 8 & $\begin{array}{l}\text { Застосування в командах із вузькопрофільни- } \\
\text { ми спеціалістами (IT, маркетинг) }\end{array}$ \\
\hline 18 & Dispersed leadership (розпорошене лідерство) & 8 & - \\
\hline
\end{tabular}




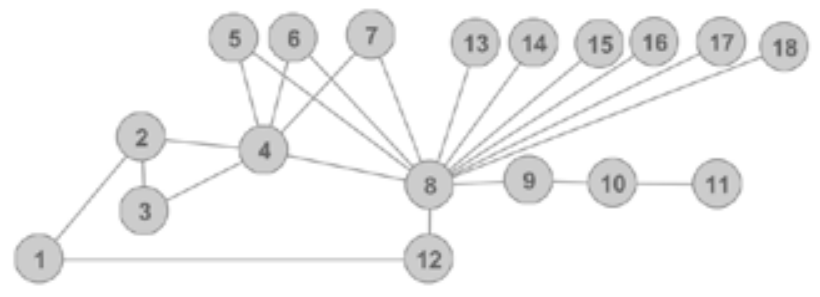

Рис. 1. Зв’язки теорій лідерства

Для візуалізації зв'зків теорій лідерства та для проведення структурного аналізу використаємо теорію графів: як вершини візьмемо теорії лідерства, а наявність ребра між вершинами означає наявність зв'зку між теоріями. Номери вершин і зв'язки будемо використовувати згідно із таблицею 3 . Результат (неорієнтований граф) - отримаємо на рис 1. Можемо побачити, що створений граф є не зв'язним. Якщо запропонувати добудувати його до рівня зв'язності, то отримаємо такий (рис. 2):

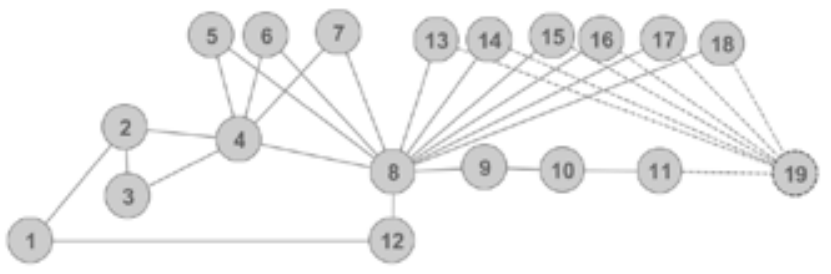

Рис. 2. Можливий розвиток теорій лідерства

Тобто для забезпечення зв'язності теорій лідерства має з'явитися нова (вершина № 19 на рис. 2), яка сформулює загальні підходи для теорій лідерства, що спрямовані на послідовників лідерів.

Висновки. У результаті розгляду теорій лідерства можемо зробити висновок, що ця сфера, з погляду наявності загальних досліджень має значну насиченість, у цій статті сформовано зв'язок між розробленими теоріями.

Варто зазначити, що розвиток теорій лідерства на сьогодні відбувається у сферах і країнах із високим рівнем продуктивних сил. 3 одного боку, це викликано необхідністю до пошуків підходів, що дозволяє витримувати високу конкуренцію та працювати в нових високотехнологічних та інформаційно-ємних сферах, а з другого - послідовники лідерів готові до нових форм лідерства.

Водночас існують і інші умови, де послідовники та лідери не готові реалізовувати нові концепції лідерства (найпростіший приклад - це те, що неможливо використовувати концепцію е-лідерства в організаціях, де не впроваджено автоматизацію). І для таких умов ефективнішою формою лідерства буде не остання, а та, яка може бути реалізована в умовах поточного розвитку продуктивних сил організації та відповідної країни.

При цьому це не складає відповідальності з лідера за розвиток організації задля того, щоб біла можлива реалізація більш розвинених форм лідерства.

Основним напрямом розвитку теорій лідерства бачиться питання оцінки середовища лідер-послідовники та формування критеріїв оцінки, що дозволять отримувати відповідь на питання про форму лідерства, що буде ефективнішою в певній ситуації.

\section{Література:}

1. Carlyle, Thomas. On Heroes, Hero-Worship and the Heroic in History, Fredrick A. Stokes \& Brother, New York, 1888. p. 2.

2. Stogdill, R. M. Personal factors associated with leadership: A survey of the literature, The Journal of psychology. 1948. №25(1). pp. 35-71.

3. Derue D. S. et al., Trait and behavioral theories of leadership: An integration and meta-analytic test of their relative validity, Personnel psychology. 2011. № 64(1). pp. 7-52.

4. Northouse P. G. Leadership: Theory and practice., 1997.

5. Greenleaf R. K. Servant leadership., 1977.

6. Чистякова I. А. Коопероване лідерство як управлінська технологія: досвід Великої Британії / I. А. Чистякова. Витоки педагогічної майстерності. Сер.: Педагогічні науки. 2011. №8(1). С. 306-312. - Режим доступу: http://nbuv.gov.ua/UJRN/vpm_2011_8(1)_64.

7. Романовський О. Г., Середа Н. В. Особистість сучасного керівника в аспекті теорії духовного лідерства. Теорія і практика управління соціальними системами. 2013. №3. С. 20-27.

8. Козак К. Б. Роль лідерства в системі управління персоналом на підприємстві. Економіка харчової промисловості. 2013. №. 3. С. 24-28. 
9. Jessica E. Dinh, Robert G. Lord, William L. Gardner, Jeremy D. Meuser,Robert C. Liden, Jinyu Hu. Leadership theory and research in the new millennium: Current theoretical trends and changing perspectives. The Leadership Quarterly Volume 25, Issue 1, pp. 36-62.

10. Portugal E., Yukl G., Perspectives on environmental leadership. The Leadership Quarterly. 1994. 5(3-4). pp. 271-276.

11. Derue D. S. et al. Trait and behavioral theories of leadership: An integration and meta $\square$ analytic test of their relative validity. Personnel psychology. 2011. №64(1). pp. 7-52.

12. Hannah S. T. et al. The psychological and neurological bases of leader self-complexity and effects on adaptive decision-making. Journal of Applied Psychology. 2013. №98(3). pp. 393.

13. House R. J., A path goal theory of leader effectiveness. Administrative science quarterly. 1971. pp. 321-339.

14. Waldman D. A., Balthazard P. A., Peterson S. J., Social cognitive neuroscience and leadership.The Leadership Quarterly. 2011. №22 (6). pp. 1092-1106.

15. Boyatzis R. E. et al., Examination of the neural substrates activated in memories of experiences with resonant and dissonant leaders. The Leadership Quarterly. 2012. №23(2). pp. 259-272.

16. Northouse P. G., Leadership: Theory and practice. 1997.

17. Lowe K. B., Kroeck K. G., Sivasubramaniam N., Effectiveness correlates of transformational and transactional leadership: A meta-analytic review of the MLQ literature. The leadership quarterly. 1996. №7(3). pp. 385-425.

18. Northouse P. G. Leadership: Theory and practice. Sage publications, 2018.

19. Greenleaf R. K. Servant leadership, 1977.

20. Pearce C. L., Conger J. A. Shared leadership: Reframing the hows and whys of leadership. - Sage, 2002.

21. Zaccaro S. J., Rittman A. L., Marks M. A. Team leadership. The leadership quarterly. 2001. №12(4). pp. 451-483.

22. Kühl S., Schnelle T., Tillmann F. Lateral leadership: An organizational approach to change. Journal of Change Management. 2005. №5. №. 2. pp. 177-189.

23. Politis J. D. Dispersed leadership predictor of the work environment for creativity and productivity. European Journal of Innovation Management. 2005. №8(2). - pp. 182-204.

24. Gronn P. Distributed leadership as a unit of analysis. The leadership quarterly. - 2002. №13(4). pp. 423-451.

25. Relationship-based approach to leadership: Development of leader-member exchange (LMX) theory of leadership over 25 years: Applying a multi-level multi-domain perspective The Leadership Quarterly Volume 6, Issue 2, Summer 1995, pp. 219-247.

26. Simone G. A. Рациональность как процесс и продукт мышления. THESIS: Теория и история экономических и социальных институтов и систем. 1993. №. 3. С. 16-38.

27. Jolls C., Sunstein C. R., Thaler R. A behavioral approach to law and economics. Stanford law review. 1998. pp. 1471-1550. 